\title{
Upregulation of the Expression of Inflammatory and Angiogenic Markers in Human Adipocytes by a Synthetic Cannabinoid, JTE-907
}

\author{
Authors \\ Affiliation
}

\section{P. González-Muniesa, C. Bing, P. Trayhurn}

Obesity Biology Research Unit, School of Clinical Sciences, University of Liverpool, UCD, Duncan Building, Liverpool, UK

\section{Key words \\ endocannabinoid system \\ - inflammation \\ - human adipose tissue \\ obesity \\ - TRPV1 \\ - $\mathrm{CB}_{1}$}

received 12.01.2010

accepted 31.05.2010

Bibliography

Dol http://dx.doi.org/

10.1055/s-0030-1255119

Published online:

July 5, 2010

Horm Metab Res 2010;

42: 710-717

(c) Georg Thieme Verlag KG

Stuttgart · New York

ISSN 0018-5043

\section{Correspondence}

Dr. P. González-Muniesa

Department of Nutrition

Food sciences

Physiology and Toxicology

University of Navarra

31008 Pamplona

Navarra

Spain

Tel.: + 34/94/8425600

(ext. 6650)

Fax: + 34/94/8425 649

pgonmun@unav.es

\section{Abstract}

$\nabla$

Inflammation in adipose tissue is a characteristic of obesity and the metabolic syndrome. It is suggested that the endocannabinoid system is involved in the regulation of inflammatory and angiogenic processes within the tissue. Human subcutaneous preadipocytes (Zen Bio) were used as the source of human preadipocytes or adipocytes. Gene expression was examined by RT-PCR and real-time PCR. The secretion of inflammation-related proteins was determined by an ELISA array. In experiments on adipocytes treated at day 14 post-differentiation, JTE-907, a synthetic cannabinoid, upregulated the expression of key inflammatory markers - IL-6, MCP-1 and IL-1 $\beta$ - and angiogenic factors - VEGF and

\section{Abbreviations}

$\nabla$

AM251

$N$-(Piperidin-1-yl)-5-

(4-iodophenyl)-1-

(2,4-dichlorophenyl)-

4-methyl-1H-pyrazole-3-

carboxamide

AM630 6-Iodo-2-methyl-1-[2-

(4-morpholinyl)ethyl]-1H-indol-3yl](4-methoxyphenyl) methanone

Arachidonyl $\mathrm{N}$-[2-(5-Hydroxy-1H-indol-

serotonin 3-yl)ethyl]-5,8,11,14-

(A.S.)

JTE-907

eicosatetraenamide

$\mathrm{N}$-(1,3-Benzodioxol-5-ylmethyl)-

1,2-dihydro-7-methoxy-2-oxo-

8-(pentyloxy)-3-

quinolinecarboxamide

\section{Introduction}

$\nabla$

The medical properties of marijuana (Cannabis sativa) led to the discovery of the endocannabinoid system (ECS) in the early 1990s, with the
ANGPTL4 - at $10 \mu \mathrm{M}$ after $20 \mathrm{~h}$ of treatment, having also increased the expression of TRPV1 at $10 \mu \mathrm{M}$. JTE-907 showed no effect after $4 \mathrm{~h}$. The ELISA array showed a 2.6-fold increase in IL-6 protein release. The effect of JTE-907 was inhibited by AM251 ( $\mathrm{CB}_{1}$ antagonist), and partially by arachidonyl serotonin (TRPV1 and FAAH antagonist). The $\mathrm{CB}_{2}$ antagonist, AM630, partially upregulated the effect of JTE-907. Preadipocytes fed 14 days after $100 \%$ confluence exhibited downregulation of $\mathrm{CB}_{1}, \mathrm{MCP}-1$, and IL- $1 \beta, 20 \mathrm{~h}$ after having been exposed to JTE-907. $\mathrm{CB}_{1}$ and TRPV1 receptors participate in the regulation of several inflammatory and angiogenic factors in human adipocytes, indicating their potential value as targets for the treatment of disorders related to obesity.

cloning of the cannabinoid receptors $\mathrm{CB}_{1}$ and $\mathrm{CB}_{2}$ (nomenclature follows Alexander, Mathie, and Peters [1]), and subsequently the discovery of the first endocannabinoids, anandamide and 2-arachidonoylglycerol (2-AG) [2-4]. More recently, other putative ECS receptors, such as TRPV1 (transient receptor potential cation channel, subfamily V, member 1) and GPR55 (G protein-coupled receptor 55$)$, have been recognized $[5,6]$. The tissues and organs where the various ECS receptors are expressed is still unclear, but in humans the $C_{1}$ receptor is mainly expressed in the brain with some expression in a range of other tissues, including kidney, liver, lung, skeletal muscle, and adipose tissue [7-9]. The TRPV1 receptor is highly expressed in human sensory neurons [10], but it is also expressed in human adipose tissue [11]. On the other hand, the $\mathrm{CB}_{2}$ receptor is expressed in macrophages [12] and expression is also reported in the rat central nervous system [13], while there is some controversy about its presence in human adipose tissue depots $[9,11]$. 
The list of ligands of the cannabinoid receptors is extensive and is divided into 3 categories: phytocannabinoids (from plants), endocannabinoids (endogenous cannabinoids), and synthetic cannabinoids (developed as putative drugs). JTE-907, which is in this last category, binds to $\mathrm{CB}_{1}$ and $\mathrm{CB}_{2}$ cannabinoid receptors with a higher affinity for the latter [14]. This synthetic compound appears to be an anti-inflammatory or antiallergic agent [15-17]. The ECS and its receptors $\mathrm{CB}_{1}$, TRPV1, and $\mathrm{CB}_{2}$ have been linked to a wide range of functions, including: vascular and endocrine responses, neuroprotection and nociception, immune modulation, stress recovery, food intake, energy balance, and metabolic homeostasis [18-20]. Of particular interest is the role of the ECS in appetite and the regulation of energy balance [21], $\mathrm{CB}_{1}$ receptor blockade in animals and humans producing a reduction in body weight and an improvement of the comorbidities of obesity [22,23].

Obesity is a major public health problem in most developed countries and in the UK, for example, $25 \%$ of adults are now clinically obese with a BMI $\geq 30$. Obesity is characterized by chronic low grade inflammation [24-26] and this has been linked to the development of the associated comorbidities, particularly the components of the metabolic syndrome $[27,28]$. Adipose tissue is a major site of inflammation in obesity, with the adipocytes secreting a number of cytokines, chemokines, and other inflammation-related factors, including those involved in angiogenesis $[26,29]$. Several studies have demonstrated the importance of the ECS in inflammatory processes and angiogenic events; for example, in human macrophages [30], mouse obese models [20], mouse cutaneous tissue [17], rat mesenteric arteries, and human cerebral artery endothelial cells $[17,30,31]$. Little is known, however, of the genes whose expression may be modulated through the endocannabinoid system.

The aim of the present study was to examine the effects of the ECS on the expression of key inflammatory and angiogenic genes in human white adipocytes. The results suggest that $\mathrm{CB}_{1}$ and TRPV1 receptors participate in the regulation of several important inflammatory and angiogenic factors in human adipocytes and preadipocytes. These key cannabinoid receptors could be a target for the pharmacotherapy of inflammatory and angiogenic events within adipose tissue.

\section{Materials and Methods}

$\nabla$

\section{Cell culture}

Human subcutaneous preadipocytes and culture media were obtained from Zen-Bio (Durham, NC, USA) and cultured as previously [32]. Cells were from 5 female patients of average age 45.6 years and with a mean BMI of 27.9. The cells were plated at a density of $40000 / \mathrm{cm}^{2}$ onto a 24-well plate and maintained in preadipocyte medium (PM) containing DMEM/Ham's F-12 (1:1, $\mathrm{v} / \mathrm{v}), 10 \%$ fetal calf serum (FCS), $15 \mathrm{mM}$ HEPES, $100 \mathrm{U} / \mathrm{ml}$ penicillin, $100 \mu \mathrm{g} / \mathrm{ml}$ streptomycin, and $0.25 \mu \mathrm{g} / \mathrm{ml}$ amphotericin B at $37^{\circ} \mathrm{C}$ in a humidified atmosphere of $95 \%$ air $/ 5 \% \mathrm{CO}_{2}$. The cells were induced at confluence by incubation in differentiation medium composed of adipose medium (AM) supplemented with $0.25 \mathrm{mM}$ isobutylmethylxanthine and $10 \mu \mathrm{M}$ of a PPAR agonist for 5 days. The cells were then cultured with AM containing DMEM/Ham's F-12 (1:1, v/v), 3\% FCS, $100 \mathrm{nM}$ insulin, $1 \mu \mathrm{M}$ dexamethasone, $100 \mathrm{U} / \mathrm{ml}$ penicillin, $100 \mu \mathrm{g} / \mathrm{ml}$ streptomycin, and $0.25 \mu \mathrm{g} / \mathrm{ml}$ amphotericin B [33]. The medium was changed every 3 days.
Preadipocytes (fed 14 days after $100 \%$ confluence) were exposed to JTE-907 $(10 \mu \mathrm{M})$ for $20 \mathrm{~h}$. Fully differentiated cells at day 14 post-induction were exposed to JTE-907 $(1 \mu \mathrm{M}$ or $10 \mu \mathrm{M})$ for 4 or $20 \mathrm{~h}$, and to AM251 (100 nM), A.S. (arachidonyl serotonin, $10 \mu \mathrm{M}$ ) and AM630 $(10 \mu \mathrm{M})$ (all reagents were from Tocris Bioscience, Bristol, UK). The cells were harvested in $500 \mathrm{ml}$ TRI ${ }^{\circledR}$ Reagent (Sigma-Aldrich, St. Louis, MO, USA). Culture media were also collected. All incubations at each time point were performed in replicates of up to 6 wells.

\section{RNA extraction and RT-PCR}

Total RNA was isolated from cells using TRI ${ }^{\circledR}$ reagent and treated with Turbo DNA-free ${ }^{\mathrm{TM}}$ (Applied Biosystems/Ambion, Austin, TX, USA) according to the manufacturer's instructions. $1 \mu \mathrm{g}$ of DNaseI-treated RNA was reverse transcribed to obtain CDNA with Reverse-iT 1st Strand Synthesis kit (Abgene, Epsom, UK) in the presence of anchored oligo dT in a total volume of $20 \mu \mathrm{l}$.

Primers were designed using Primer Premier 5 software (Biosoft International, Palo Alto, CA, USA) and synthesized by MWG Biotech (Ebersberg, Germany). Primer sequence, size of the amplified fragments, and optimal conditions of amplification were as follows.

Bactin (281 bp): 5'-GTGGCATCCACGAAACTACCTT-3' (forward), 5'-GGACTCGTCATACTCCTGCTTG-3' (reverse), 23 cycles and annealing temperature $57^{\circ} \mathrm{C}$;

$\mathrm{CB}_{1}$ (298 bp): 5'-CAGCGTGGCACCCAGAAGA-3' (forward), 5'CGGAAAGCGTGTCGCAGGT-3' (reverse), 35 cycles and annealing temperature $60.6^{\circ} \mathrm{C}$;

TRPV1 (485 bp): 5'-TGTGCCGTTTCATGTTTGTC-3' (forward), 5'GTCGTCCTTGCCATCAGGT-3' (reverse), 40 cycles and annealing temperature $55.9^{\circ} \mathrm{C}$.

$\mathrm{CB}_{2}$ (454 bp): 5'-GGCAGCGTGACTATGACCTT-3' (forward), 5'AGCACTGGGAACCAACAGAT-3' (reverse), 45 cycles and annealing temperature $57.3^{\circ} \mathrm{C}$.

Standard-PCR was performed with $1 \mu \mathrm{l}$ of CDNA and specific primers $(0.2 \mu \mathrm{M}$ forward and $0.2 \mu \mathrm{M}$ reverse $)$ and $22.5 \mu \mathrm{l}$ of Ready Mix PCR Master Mix (Abgene) in a total volume of $25 \mu \mathrm{l}$ on a PCR Express thermal cycler. PCR conditions were as follows: $2 \mathrm{~min}$ at $94^{\circ} \mathrm{C}$ for denaturation, followed by optimal cycles of $20 \mathrm{~s}$ at $94^{\circ} \mathrm{C}$ for denaturation, $30 \mathrm{~s}$ at the optimal annealing temperature, and $40 \mathrm{~s}$ at $72^{\circ} \mathrm{C}$ for extension, with a final elongation step of $10 \mathrm{~min}$ at $72^{\circ} \mathrm{C}$. Negative controls without templates were performed to exclude the formation of primer dimers. All primer pairs produced a single specific band. PCR products were analyzed by electrophoresis on a $1 \%$ agarose gel with ethidium bromide staining and photographed under UV transillumination. The products were sequenced by MWG Biotech (Ebersberg, Germany) to confirm their identity.

\section{Real-time PCR}

Quantitative real-time PCR was carried out in a final volume of $12.5 \mu \mathrm{l}$ consisting of $12.5-100 \mathrm{ng}$ reverse-transcribed cDNA mixed with optimal concentrations of primers and probe and qPCR Core kit (Eurogentec, Southampton, UK) in 96-well plates on a Stratagene $\mathrm{M} \times 3005 \mathrm{P}$ detector. The primer and probe sets were designed using Primer Express software (Applied Biosystems) and synthesized commercially (Eurogentec). The sequence and optimal concentrations of primers and probes together with the size of products were as detailed previously for $\beta$-actin, IL-6 (interleukin 6), MCP-1 (monocyte chemotactic protein-1), TNFo (tumor necrosis factor-alpha), and ANGPTL4 (FIAF, angiopoietin- 
like protein 4) [33,34]. $\mathrm{CB}_{1}$, TRPV1, VEGF (vascular endothelial growth factor) and IL-1 $\beta$ were as follows.

$\mathrm{CB}_{1}$ : 5'-CTCATTAAGACGGTGTTTGCATTC-3' (forward), 5'-CGTGTCGCAGGTCCTTACTC-3' (reverse) and 5'-FAM-TGCTCTGCCTGCTGAACTCCACCG-TAMRA-3' (probe);

TRPV1: 5'-TGCTGGCCTATGTAATTCTCACC-3' (forward), 5'-TCTTCTCCGTGTCCAGGATGG-3' (reverse) and 5'-FAM-CATCCTCCTGCTCAACATGCTCATCGCC-TAMRA-3' (probe);

VEGF: 5'-TGAGATCGAGTACATCTTCAAGCC-3' (forward), 5'GTGAGGTTTGATCCGCATAATCTG-3' (reverse) and 5'-FAM-CCTGTGTGCCCCTGATGCGATGCG-TAMRA-3' (probe);

IL-1ß: 5'-TGGCCCTAAACAGATGAAGTGC-3' (forward), 5'-GTAGTGGTGGTCGGAGATTCG-3' (reverse) and 5'-FAM-ACCTGGACCTCTGCCCTCTGGATGG-TAMRA-3' (probe).

Typically, the amplification started with $2 \mathrm{~min}$ at $50^{\circ} \mathrm{C}, 10 \mathrm{~min}$ at $95^{\circ} \mathrm{C}$, and then 40 cycles of the following: $15 \mathrm{~s}$ at $95^{\circ} \mathrm{C}$ and $1 \mathrm{~min}$ at $60^{\circ} \mathrm{C}$.

Human $\beta$-actin was used as an endogenous reference; its expression remained unchanged both in response to the various treatments and during preadipocyte differentiation. Relative quantitation values were expressed using the $2^{-\Delta \Delta C t}$ method (see User Bulletin 2, ABI PRISM 7700, pp 11-15, Applied Biosystems) as fold changes in the target gene normalized to the reference gene ( $\beta$-actin) and related to the expression of the untreated controls. The PCR efficiency in all runs was close to $100 \%$, and all samples were analyzed in at least duplicate.

\section{Measurement of adipokines by ELISA}

IL-6, MCP-1, TNF $\alpha$, and IL-1 $\beta$ were measured in cell culture media among 8 other proteins using a commercial ELISA array for autoimmune disease (MEH-005A; SABiosciences Corporation, Frederick, USA). The assays were conducted in 96-well microplates, according to the manufacturer's instructions.

\section{Statistical analysis}

The statistical significance of differences between groups was assessed by Student's $t$-test. A p-value of $<0.05$ was considered to be statistically significant.

\section{Results}

$\nabla$

Expression of cannabinoid receptor genes in

differentiated adipocytes and preadipocytes

We first investigated whether the human white adipocytes used here express the cannabinoid receptor genes when differentiated in culture. RT-PCR was performed on mRNA from mature adipocytes (14 days post-induction). The results showed that the mRNAs for the genes encoding $\mathrm{CB}_{1}$ and TRPV1 were present in the differentiated adipocytes at day 14 ( $\odot$ Fig. 1a by real time$P C R$ ), but $C_{2}$ was not expressed in these cells (data not shown). The pattern of expression was the same for preadipocytes. $\mathrm{CB}_{1}$ and TRPV1 were also present in preadipocytes as shown in $\bullet$ Fig. 4a (vide infra) by real time-PCR; and $\mathrm{CB}_{2}$ was not expressed in preadipocytes either (data not shown). The primers for $\mathrm{CB}_{2}$ were previously tested with mRNA obtained from a human macrophage-like cell line (U937) as a positive control, attaining a clear signal, which was confirmed by sequencing.
Upregulation of cannabinoid receptors, inflammatory, and angiogenic genes by JTE-907

In pilot experiments, the effects of several $\mathrm{CB}_{1}$ and $\mathrm{CB}_{2}$ agonists and antagonists, at different doses, on the expression of inflammation-related genes in human adipocytes were examined and particularly strong responses were obtained with JTE-907 (results not shown). In subsequent experiments, human preadipocytes were differentiated and exposed to JTE-907 at day 14 post-induction at which time they contained multiple lipid droplets. The mRNA levels of several genes were measured $20 \mathrm{~h}$ after exposing the human adipocytes to JTE-907 at 2 different doses $(1$ and $10 \mu \mathrm{M})$ ( $\bullet$ Fig. 1). Firstly, 2 cannabinoid receptor genes $\left(\mathrm{CB}_{1}\right.$ and TRPV1) were analyzed ( $\bullet$ Fig. 1a). At $1 \mu \mathrm{M}$ no effect was found on the mRNA levels of the 2 receptors. At the second dose $(10 \mu \mathrm{M}), \mathrm{CB}_{1}$ mRNA level was not significantly changed and TRPV1 MRNA level was increased 3-fold.

Subsequently, the mRNA levels of inflammatory markers (IL-6, MCP-1, TNF $\alpha$, and IL-1 $\beta$ ) and angiogenic factors (VEGF and ANGPTL4) were quantitated ( $\bullet$ Fig. 1 b). The lowest dose $(1 \mu \mathrm{M})$ produced no effect on the mRNA level of any of the genes. The highest dose $(10 \mu \mathrm{M})$ increased IL-6, MCP-1, IL-1 $\beta$, VEGF, and ANGPTL4 mRNA levels by 41-, 7-, 6-, 6-, and 3-fold, respectively; however, this dose did not affect TNF $\alpha$ gene expression.

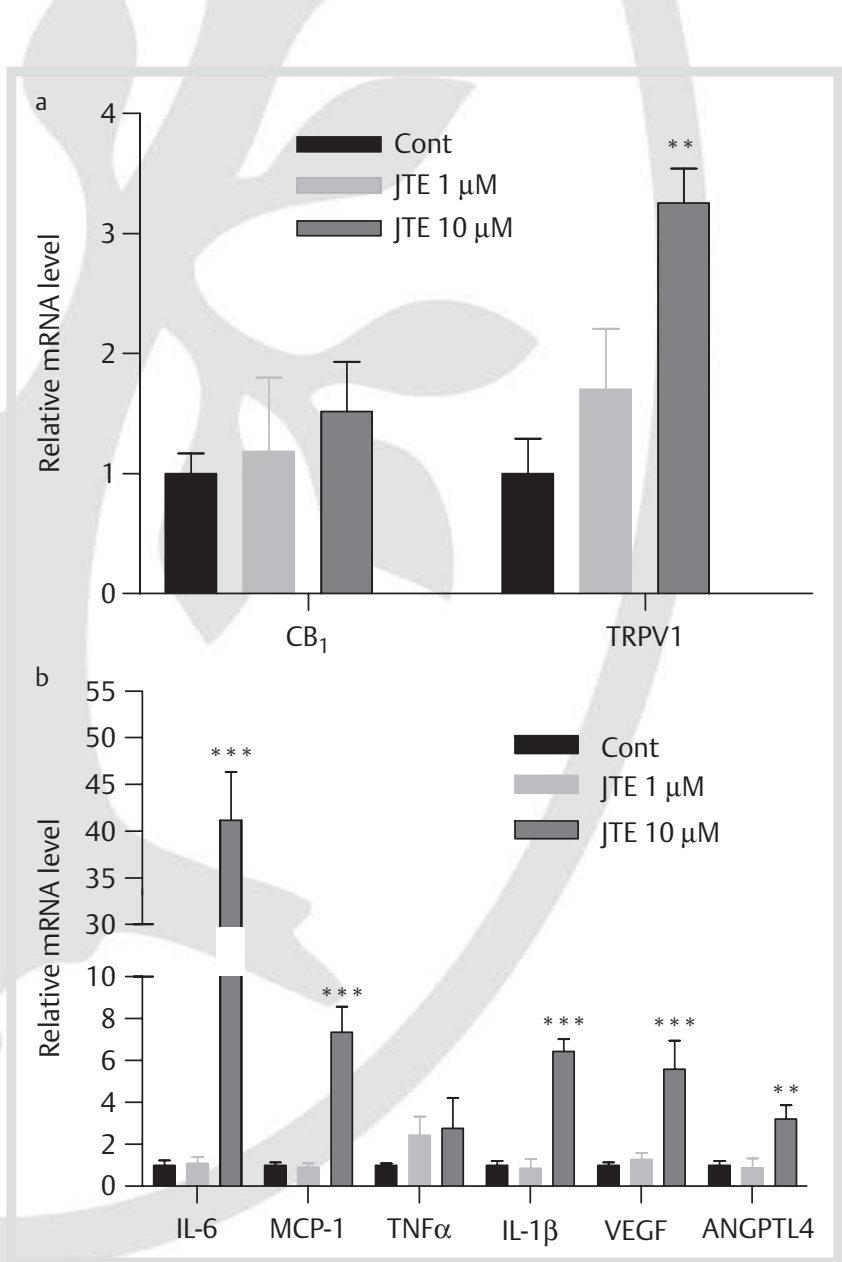

Fig. 1 Effect of JTE-907 on gene expression in human adipocytes. Differentiated human adipocytes ( 14 days) were exposed for $20 \mathrm{~h}$ to JTE-907 (1 and $10 \mu \mathrm{M})$. a: $\mathrm{CB}_{1}$ and TRPV1 gene expression. b: Expression of inflammatory marker genes and angiogenic factors. mRNA levels were normalized to human $\beta$-actin and quantitated by real time-PCR. Means \pm SE; $n=6 .{ }^{*} p<0.05,{ }^{* *} p<0.01$ and ${ }^{* * *} p<0.001$ compared with control. JTE: JTE-907. 



Fig. 2 Effect of JTE-907 on gene expression and protein secretion in human adipocytes. Differentiated human adipocytes (14 days) were exposed to JTE-907 $(10 \mu \mathrm{M})$ for 4 and $20 \mathrm{~h}$. a: $\mathrm{CB}_{1}$ and TRPV1 gene expression. $\mathbf{b}$ : Expression of inflammatory marker genes and angiogenic factors. mRNA levels were normalized to human $\beta$-actin and quantitated by real time-PCR. Means $\pm S E, n=6$. ${ }^{* *} p<0.01$ and ${ }^{* * *} p<0.001$ compared with control. c: Secretion of IL-6 protein measured by ELISA. Differentiated human adipocytes (14 days) were exposed for $20 \mathrm{~h}$ to JTE-907 $(10 \mu \mathrm{M}) ; \mathrm{n}=3$. Means \pm SE. ${ }^{* * *} \mathrm{p}<0.001$ compared with control. for $4 \mathrm{~h}$ did not result in any significant change in the level of the mRNA for any of the genes mentioned previously ( $\bullet$ Fig. 2a, b). IL-6, MCP-1, TNF $\alpha$, and IL-1 $\beta$ proteins were measured, in addition to 8 other proteins involved in autoimmune disease, in the medium using a commercial ELISA array in the cells incubated with $10 \mu \mathrm{M}$ JTE-907 for $20 \mathrm{~h}$. The ELISA array showed a 2.6-fold increase in IL-6 release ( $\bullet$ Fig. 2 c), which was statistically significant, consistent with the mRNA measurements. The secretion levels of other relevant proteins, such as TNF $\alpha$ and IL-1 $\beta$, were below the detection sensitivity of the array. There was no significant change in MCP-1 release.

\section{Effect of cannabinoid receptor antagonists on the response to JTE-907}

The upregulation of several genes by JTE-907 ( $10 \mu \mathrm{M}$ for $20 \mathrm{~h})$ on differentiated human adipocytes (14 days) was inhibited when AM251 (100 nM), a $\mathrm{CB}_{1}$ receptor antagonist, was added at the same time ( $\bullet$ ig. 3a, b). TRPV1 mRNA level was reduced 4-fold, although no significant effect was found on $\mathrm{CB}_{1}$ gene expression ( $\bullet$ Fig. 3a). The mRNA levels of IL-6, MCP-1, IL-1 $\beta$, VEGF, and ANGPTL4 decreased 29-fold, 5-fold, 3-fold, 6-fold and 3-fold, respectively; this antagonist did not affect TNF $\alpha$ gene expression (॰ Fig. 3b).

Arachidonyl serotonin (A.S.), considered to be a TRPV1 and FAAH (degrading enzyme of anandamide) antagonist [35], partially inhibited the effect of JTE-907 on differentiated (14 days) human adipocytes when the 2 agents were added together (both at $10 \mu \mathrm{M}$ for $20 \mathrm{~h}$ ) ( $\bullet$ Fig. 3c, d). TRPV1 mRNA expression was reduced 3-fold, although no significant effect was found on $\mathrm{CB}_{1}$ gene expression ( $\bullet$ Fig. 3c). The expression of IL-6, MCP-1, VEGF, and ANGPTL4 was significantly lower than with JTE-907 alone, being 10-fold, 6-fold, 5-fold, and 4-fold lower, respectively; TNF $\alpha$ and IL-1 $\beta$ gene expression remained unaltered ( $\bullet$ Fig. $3 d$ ).

Interestingly, $\mathrm{AM} 630$ (a $\mathrm{CB}_{2}$ antagonist), partially upregulated the effect of JTE-907 alone ( $\bullet$ Fig. 3e, f). AM630 and JTE-907 (both $10 \mu \mathrm{M}$ ) were added simultaneously to differentiated human adipocytes and the cells were collected $20 \mathrm{~h}$ later. $\mathrm{CB}_{1}$ and TRPV1 mRNA levels were augmented 1.5-fold and 3-fold, respectively ( $\odot$ Fig. 3e), while MCP-1 and ANGPTL4 expression was increased 2-fold and 4-fold, respectively ( $\bullet$ Fig. 3f). There was no effect of AM630 on IL-6, TNF $\alpha$, IL-1 $\beta$, and VEGF gene expression ( $\odot$ Fig. 3f).

\section{Differential effects of JTE-907 on the expression of preadipocytes genes}

The effect of JTE-907 on the expression in preadipocytes of those genes sensitive to the compound in adipocytes was then examined. Human preadipocytes were fed 14 days after reaching $100 \%$ confluence and exposed to JTE-907 at $10 \mu \mathrm{M}$ for $20 \mathrm{~h}$ ( $\bullet$ Fig. 4). Expression of the $\mathrm{CB}_{1}$ receptor was slightly downregulated (56\% reduction) in preadipocytes with no significant effect in mature adipocytes ( $\bullet$ Fig. 4a). The mRNA level of 2 genes involved in inflammation, MCP-1 and IL-1 $\beta$, was reduced by approximately $60 \%$ in preadipocytes ( $\bullet$ Fig. 4 b), which was in contrast to increases of more than $700 \%$ and $600 \%$, respectively, in mature adipocytes ( $\bullet$ Fig. 1b).

\section{Discussion and Conclusions} $\nabla$

The high and growing incidence of obesity and its associated disorders now represents a major public health problem [36]. 


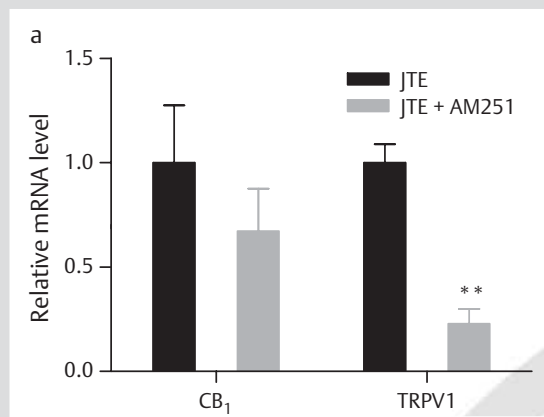

c
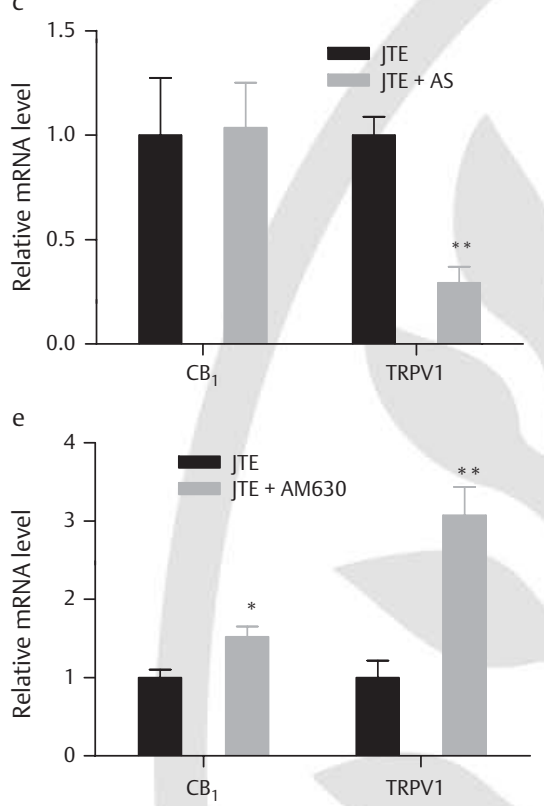

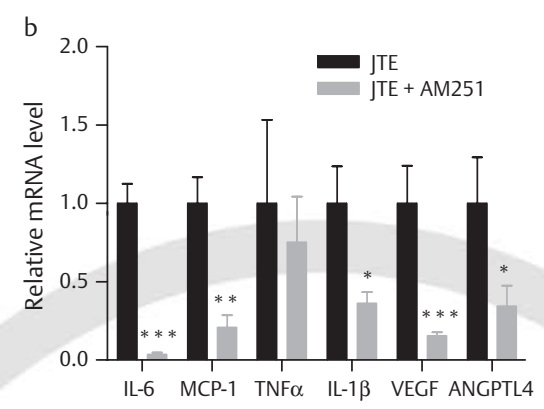

d



$f$



Fig. 3 Inhibition or upregulation of JTE-907 effect on gene expression by antagonists of $\mathrm{CB}_{1}$, TRPV1 and $\mathrm{CB}_{2}$. $\mathbf{a}$ and $\mathbf{b}$ : Differentiated human adipocytes ( 14 days) were exposed for $20 \mathrm{~h}$ to JTE-907 $(10 \mu \mathrm{M})$ and JTE-907 $(10 \mu \mathrm{M})+\mathrm{AM} 251(100 \mathrm{nM})$. a. $\mathrm{CB}_{1}$ and TRPV1 gene expression. $\mathbf{b}$ : Expression of inflammatory marker genes and angiogenic factors $\mathbf{c}$ and $\mathbf{d}$ : Differentiated human adipocytes (14 days) were exposed for $20 \mathrm{~h}$ to JTE-907 $(10 \mu \mathrm{M})$ and JTE-907 + A.S. (both $10 \mu \mathrm{M})$. c: $\mathrm{CB}_{1}$ and TRPV1 gene expression. $\mathbf{d}$ : Gene expression of inflammatory markers and angiogenic factors $\mathbf{e}$ and $\mathbf{f}$. Differentiated human adipocytes (14 days) were exposed for $20 \mathrm{~h}$ to JTE-907 $(10 \mu \mathrm{M})$ and JTE-907 + AM630 (both $10 \mu \mathrm{M})$. e: $\mathrm{CB}_{1}$ and TRPV1 gene expression. f: Expression of inflammatory marker genes and angiogenic factors. mRNA levels were normalized to human $\beta$-actin. Means \pm SE; $n=6$. ${ }^{*} p<0.05$ and ${ }^{* *} \mathrm{p}<0.01$ compared with JTE-907.
The endocannabinoid system and its relation with metabolism, inflammation, and angiogenesis have been considered as one of the key targets in the treatment of obesity and its comorbidities, among other diseases $[7,18,37,38]$. Cannabinoid receptors are mainly expressed in the central nervous system, but their peripheral location and effects are becoming of increasing interest $[30,39]$. The present study has examined the effects of JTE907, a synthetic cannabinoid [14], on the expression of 2 receptors of the ECS $\left(\mathrm{CB}_{1}\right.$ and TRPV1) and on the expression of major adipokine genes in preadipocytes and in mature adipocytes.

White adipose tissue secretes a large number of protein signals and protein factors, termed adipokines. The production and circulating level of some of these adipokines is increased in obese patients, for example IL-6, MCP-1, and TNF $\alpha[25,40]$ while their gene expression is reduced in adipose tissue after weight loss, as is the case with IL-1 $\beta$ [41]. The expression of some adipokines, such as leptin, VEGF, ANGPTL4 [32], and RANTES (an immune mediator) [42], is increased under hypoxic conditions, and low oxygen tension has been proposed as a key trigger for the mild chronic inflammatory state associated with obesity [26]. Furthermore, there is a link between these adipokines and the comorbidities associated with obesity $[43,44]$.

Within human white adipose tissue, $\mathrm{CB}_{2}$ gene and protein expression in preadipocytes and mature adipocytes isolated from omental and subcutaneous tissue has been reported by some authors [9], while others [11] were unable to detect $\mathrm{CB}_{2}$ gene expression in adipocytes and tissue from the subcutaneous fat depot. Our results are consistent with the latter, confirming the expression of $\mathrm{CB}_{1}$ and TRPV1, but not of $\mathrm{CB}_{2}$ in human adipocytes.

The key findings from the present study are that JTE-907 is able to regulate the expression of receptor genes, which are part of the ECS $\left(\mathrm{CB}_{1}\right.$ and TRPV1 receptors), together with a proinflammatory behavior and the upregulation of genes associated with angiogenesis (VEGF and ANGPTL4). Previous studies have shown that JTE907 has an anti-inflammatory action in mouse cutaneous tissue [14-17], but no effect of JTE-907 has been found in human colon [45]. In these investigations, JTE-907 was believed to be acting through the $\mathrm{CB}_{2}$ receptor; however, in our study, due to the absence of expression of $\mathrm{CB}_{2}$ receptors in human adipocytes the actions of this ligand are more likely to occur through $\mathrm{CB}_{1}$ or TRPV1.

Therefore, the cells were exposed to an antagonist of $\mathrm{CB}_{1}$ (AM251), $\mathrm{CB}_{2}$ (AM-630) and TRPV1 and FAAH (arachidonoyl serotonin) in different experiments, in order to determine the probable route of action of JTE-907 within human white adipocytes. Interestingly, the compound appeared to operate through $\mathrm{CB}_{1}$ and TRPV1, either acting through both directly or through 1 receptor, which would subsequently activate the second; the last mechanism has been demonstrated by other authors $[19,46]$. The importance of the TRPV1 receptor in obesity is unclear, with 2 important studies showing contrasting results $[47,48]$. AM630, an antagonist or inverse agonist for $\mathrm{CB}_{2}$, which may act as an inverse agonist [49] or weak partial agonist of the $C_{1}$ receptor [50], augmented the effects obtained with JTE-907 alone in the case of genes such as $\mathrm{CB}_{1}$, TRPV1, MCP-1, and ANGPTL4. 


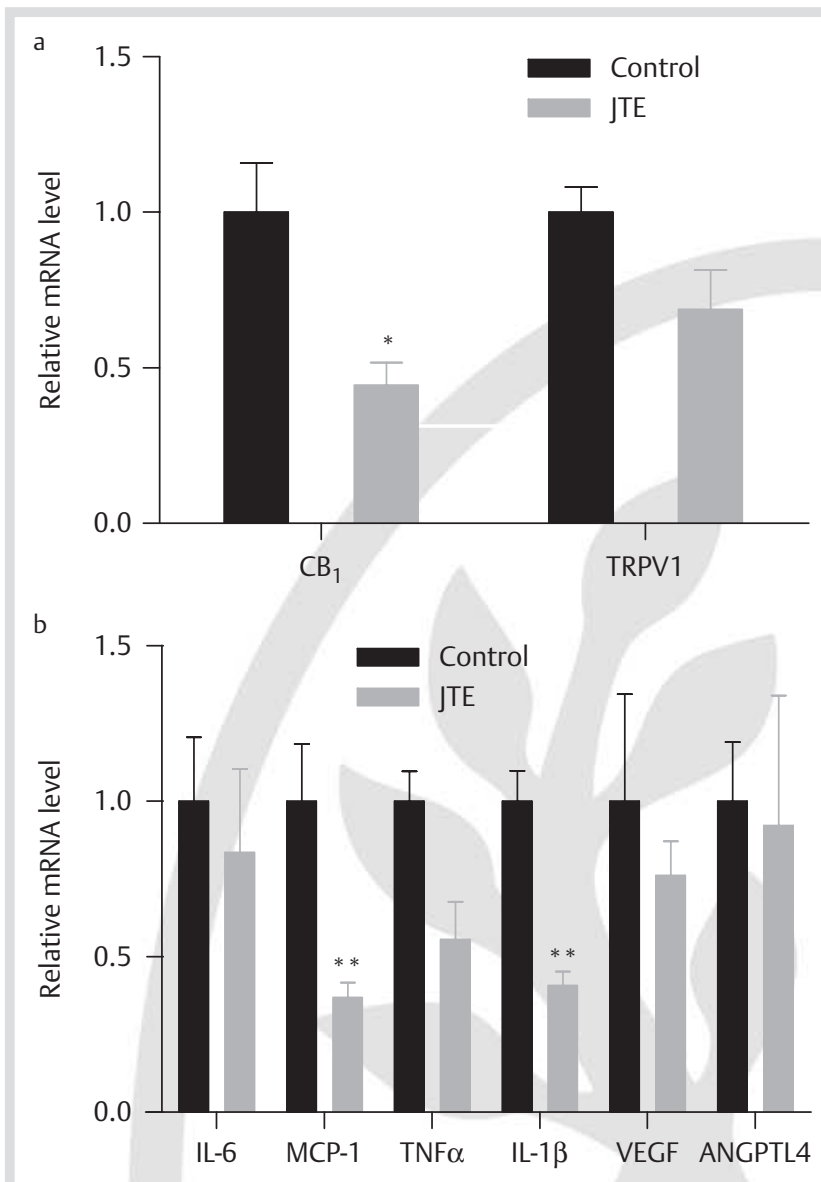

Fig. 4 Downregulation of $\mathrm{CB}_{1}, \mathrm{MCP}-1$, and IL-1 $\beta$ gene expression in human preadipocytes by JTE-907. Human preadipocytes fed 14 days after $100 \%$ confluence were exposed for $20 \mathrm{~h}$ to JTE-907 $(10 \mu \mathrm{M})$. a: $\mathrm{CB}_{1}$ and TRPV1 gene expression. $\mathbf{b}$ : Expression of inflammatory marker genes and angiogenic factors. mRNA levels were normalized to human $\beta$-actin. Means \pm SE; $n=6 .{ }^{* *} \mathrm{p}<0.01$ compared with control.

In a recent study, Hoareau et al. [51] reported anti-inflammatory actions of SR141716 (also known as Rimonabant, a $\mathrm{CB}_{1}$ antagonist) and SR144528 (a CB 2 antagonist) against LPS stimulation in mature adipocytes obtained from human subcutaneous adipose tissue, with stronger effects with the latter. These and other recent results confirming the anti-inflammatory actions of a $\mathrm{CB}_{1}$ antagonist like Rimonabant [30,52], may support the idea that AM630 and JTE-907 are exerting their proinflammatory actions as agonists of $C_{1}$. In addition, there is evidence relating some $\mathrm{CB}_{1}$ agonists with anti-inflammatory actions, such as WIN55,2122 [53,54], ACEA [55] or anandamide $\left(\mathrm{CB}_{1}\right.$ and $\mathrm{CB}_{2}$ agonist) [56], or with proinflammatory actions, like anandamide [57]. This confirms the fact that different or even the same, endocannabinoids may work in opposite ways. The increased secretion of IL6 protein in response to JTE-907 underlines the proinflammatory property of this compound in human adipocytes and indicates that the changes in gene expression are reflected by parallel alterations in the amount of the encoded protein.

The relationship between angiogenesis and JTE-907 has not been described previously. Furthermore, it is the first time this synthetic cannabinoid has been found to upregulate the expression of genes associated with a proinflammatory state and to have a proangiogenic effect. The receptors, $\mathrm{CB}_{1}$ and TRPV1, have been linked to inflammation and cardiovascular responses
$[18,19]$. This would indicate that in adipocytes JTE-907 might be acting as an agonist for these receptors.

There is increasing recognition of the importance of other cells, apart from mature adipocytes, in the function of white adipose tissue, including inflammation. This is particularly evident with respect to macrophages which are recruited during the expansion of adipose mass in obesity, and this is considered to be a key component of the inflammatory response. Preadipocytes are also increasingly recognized to be major players in adipose tissue inflammation $[58,59]$. However, JTE-907 did not affect in preadipocytes those same genes that were upregulated in the mature adipocytes. In practise, for those genes in preadipocytes that were influenced by the treatment, there was a downregulation in contrast to the upregulation in the mature adipocytes. Previous studies have shown that the preadipocytes may show a similar, or opposite, behavior to mature adipocytes, depending on the parameter $[60,61]$.

Inflammation and angiogenesis are key processes in obesity, the metabolic syndrome, and a number of other diseases. The present study suggests that $\mathrm{CB}_{1}$ and TRPV1 receptors participate in the regulation of the expression of several important inflammatory and angiogenic gene factors in human mature adipocytes. Understanding the mechanism of action of the different cannabinoid receptors within adipose tissue and other peripheral sites may be valuable in the development of pharmacological treatments for obesity-associated diseases.

\section{Acknowledgements \\ $\nabla$}

We are grateful to Mr. Leif Hunter and Ms. Tanya Romacho for their help; we also gratefully acknowledge the receipt of funding from the BBSRC (UK, No. BBE0095221). PT is a member of COST BM0602.

\section{References}

1 Alexander SP, Mathie A, Peters JA. Guide to Receptors and Channels (GRAC), $3^{\text {rd }}$ ed. Br J Pharmacol 2008; 153 (Suppl 2): S1-S209

2 Devane WA, Hanus L, Breuer A, Pertwee RG, Stevenson LA, Griffin G, Gibson D, Mandelbaum A, Etinger A, Mechoulam R. Isolation and structure of a brain constituent that binds to the cannabinoid receptor. Science 1992; 258: 1946-1949

3 Mechoulam R, Ben-Shabat S, Hanus L, Ligumsky M, Kaminski NE, Schatz AR, Gopher A, Almog S, Martin BR, Compton DR, Pertwee RG, Griffin G, Bayewitch M, Barg J, Vogel Z. Identification of an endogenous 2monoglyceride, present in canine gut, that binds to cannabinoid receptors. Biochem Pharmacol 1995; 50: 83-90

4 Sugiura T, Kondo S, Sukagawa A, Nakane S, Shinoda A, Itoh K, Yamashita A, Waku K. 2-Arachidonoylglycerol: a possible endogenous cannabinoid receptor ligand in brain. Biochem Biophys Res Commun 1995; 215: 89-97

5 Brown AJ. Novel cannabinoid receptors. Br J Pharmacol 2007; 152: 567-575

6 Pertwee RG. GPR55: a new member of the cannabinoid receptor clan? Br J Pharmacol 2007; 152: 984-986

7 Di Marzo V, Bifulco M, De Petrocellis L. The endocannabinoid system and its therapeutic exploitation. Nat Rev Drug Discov 2004; 3: 771-784

8 Pagotto U, Marsicano G, Cota D, Lutz B, Pasquali R. The emerging role of the endocannabinoid system in endocrine regulation and energy balance. Endocr Rev 2006; 27: 73-100

9 Roche R, Hoareau L, Bes-Houtmann S, Gonthier MP, Laborde C, Baron $J F$, Haffaf Y, Cesari M, Festy F. Presence of the cannabinoid receptors, CB1 and CB2, in human omental and subcutaneous adipocytes. Histochem Cell Biol 2006; 126: 177-187

10 Geppetti P, Trevisani M. Activation and sensitisation of the vanilloid receptor: role in gastrointestinal inflammation and function. Br J Pharmacol 2004; 141: 1313-1320 
11 Spoto B, Fezza F, Parlongo G, Battista N, Sgro E, Gasperi V, Zoccali C, Maccarrone M. Human adipose tissue binds and metabolizes the endocannabinoids anandamide and 2-arachidonoylglycerol. Biochimie 2006; 88: 1889-1897

12 Munro S, Thomas KL, Abu-Shaar M. Molecular characterization of a peripheral receptor for cannabinoids. Nature 1993; 365: 61-65

13 Van Sickle MD, Duncan M, Kingsley PJ, Mouihate A, Urbani P, Mackie K, Stella N, Makriyannis A, Piomelli D, Davison JS, Marnett LJ, Di Marzo V, Pittman QJ, Patel KD, Sharkey KA. Identification and functional characterization of brainstem cannabinoid CB2 receptors. Science 2005; 310: 329-332

14 Iwamura $H$, Suzuki $H$, Ueda $Y$, Kaya $T$, Inaba $T$. In vitro and in vivo pharmacological characterization of JTE-907, a novel selective ligand for cannabinoid CB2 receptor. J Pharmacol Exp Ther 2001; 296: 420-425

15 Maekawa T, Nojima H, Kuraishi Y, Aisaka K. The cannabinoid CB2 receptor inverse agonist JTE-907 suppresses spontaneous itch-associated responses of NC mice, a model of atopic dermatitis. Eur J Pharmacol 2006; 542: 179-183

16 Ueda $Y$, Miyagawa $N$, Matsui $T$, Kaya $T$, Iwamura $H$. Involvement of cannabinoid $\mathrm{CB}(2)$ receptor-mediated response and efficacy of cannabinoid $\mathrm{CB}(2)$ receptor inverse agonist, JTE-907, in cutaneous inflammation in mice. Eur J Pharmacol 2005; 520: 164-171

17 Ueda Y, Miyagawa N, Wakitani K. Involvement of cannabinoid CB2 receptors in the IgE-mediated triphasic cutaneous reaction in mice. Life Sci 2007; 80: 414-419

18 Di Marzo V. Targeting the endocannabinoid system: to enhance or reduce? Nat Rev Drug Discov 2008; 7: 438-455

19 Szallasi A, Cortright DN, Blum CA, Eid SR. The vanilloid receptor TRPV1: 10 years from channel cloning to antagonist proof-of-concept. Nat Rev Drug Discov 2007; 6: 357-372

20 Deveaux V, Cadoudal T, Ichigotani Y, Teixeira-Clerc F, Louvet A, Manin $S$, Nhieu JT, Belot MP, Zimmer A, Even P, Cani PD, Knauf C, Burcelin R, Bertola A, Le Marchand-Brustel Y, Gual P, Mallat A, Lotersztajn S. Cannabinoid $\mathrm{CB} 2$ receptor potentiates obesity-associated inflammation, insulin resistance and hepatic steatosis. PLoS One 2009; 4: e5844

$21 \mathrm{Di}$ Marzo $\mathrm{V}$. The endocannabinoid system in obesity and type 2 diabetes. Diabetologia 2008; 51: 1356-1367

22 Di Marzo V, Despres JP. CB1 antagonists for obesity - what lessons have we learned from rimonabant? Nat Rev Endocrinol 2009; 5: 633-638

23 Rinaldi-Carmona M, Barth F, Heaulme M, Shire D, Calandra B, Congy C, Martinez S, Maruani J, Neliat G, Caput D, Ferrara P, Soubrie P, Breliere $J C$, Lefur G. SR141716A, a potent and selective antagonist of the brain cannabinoid receptor. FEBS Lett 1994; 350: 240-244

24 Wexler DJ, Hu FB, Manson JE, Rifai N, Meigs JB. Mediating effects of inflammatory biomarkers on insulin resistance associated with obesity. Obes Res 2005; 13: 1772-1783

25 Yudkin JS, Juhan-Vague I, Hawe E, Humphries SE, di Minno G, Margaglione M, Tremoli E, Kooistra T, Morange PE, Lundman P, MohamedAli $V$, Hamsten A. Low-grade inflammation may play a role in the etiology of the metabolic syndrome in patients with coronary heart disease: the HIFMECH study. Metabolism 2004; 53: 852-857

26 Trayhurn P, Wood IS. Adipokines: inflammation and the pleiotropic role of white adipose tissue. Br J Nutr 2004; 92: 347-355

27 Rasouli N, Kern PA. Adipocytokines and the metabolic complications of obesity. J Clin Endocrinol Metab 2008; 93: S64-S73

28 Shah A, Mehta N, Reilly MP. Adipose inflammation, insulin resistance, and cardiovascular disease. J Parenter Enteral Nutr 2008; 32: 638-644

29 Trayhurn P, Wood IS. Signalling role of adipose tissue: adipokines and inflammation in obesity. Biochem Soc Trans 2005; 33: 1078-1081

30 Sugamura K, Sugiyama S, Nozaki T, Matsuzawa Y, Izumiya Y, Miyata K, Nakayama M, Kaikita K, Obata T, Takeya M, Ogawa H. Activated endocannabinoid system in coronary artery disease and antiinflammatory effects of cannabinoid 1 receptor blockade on macrophages. Circulation 2009; 119: 28-36

31 Yao X, Garland CJ. Recent developments in vascular endothelial cell transient receptor potential channels. Circ Res 2005; 97: 853-863

32 Wang B, Wood IS, Trayhurn P. Dysregulation of the expression and secretion of inflammation-related adipokines by hypoxia in human adipocytes. Pflugers Arch 2007; 455: 479-492

33 Wang B, Jenkins JR, Trayhurn P. Expression and secretion of inflammation-related adipokines by human adipocytes differentiated in culture: integrated response to TNF-alpha. Am J Physiol Endocrinol Metab 2005; 288: E731-E740

34 Wang B, Trayhurn P. Acute and prolonged effects of TNF-alpha on the expression and secretion of inflammation-related adipokines by human adipocytes differentiated in culture. Pflugers Arch 2006; 452: 418-427
35 Maione S, De Petrocellis L, de Novellis V, Moriello AS, Petrosino S, Palazzo E, Rossi FS, Woodward DF, Di Marzo V. Analgesic actions of N-arachidonoyl-serotonin, a fatty acid amide hydrolase inhibitor with antagonistic activity at vanilloid TRPV1 receptors. Br J Pharmacol 2007; 150: 766-781

36 WHO. Obesity: preventing and managing the global epidemic. Report of a WHO consultation. World Health Organ Tech Rep Ser 2000; 894 (i-xii): 1-253

37 Pertwee RG. Pharmacological actions of cannabinoids. Handb Exp Pharmacol 2005;1-51

38 Pertwee RG. Cannabinoid pharmacology: the first 66 years. Br J Pharmacol 2006; 147 (Suppl 1): S163-S171

39 Nogueiras R, Veyrat-Durebex C, Suchanek PM, Klein M, Tschop J, Caldwell C, Woods SC, Wittmann G, Watanabe M, Liposits Z, Fekete C, Reizes O, Rohner-Jeanrenaud F, Tschop MH. Peripheral, but not central, CB1 antagonism provides food intake-independent metabolic benefits in diet-induced obese rats. Diabetes 2008; 57: 2977-2991

40 Dahlman I, Kaaman M, Olsson T, Tan GD, Bickerton AS, Wahlen $K$, Andersson J, Nordstrom EA, Blomqvist L, Sjogren A, Forsgren M, Attersand A, Arner P. A unique role of monocyte chemoattractant protein 1 among chemokines in adipose tissue of obese subjects. J Clin Endocrinol Metab 2005; 90: 5834-5840

41 de Mello VD, Kolehmainen M, Schwab U, Mager U, Laaksonen DE, Pulkkinen L, Niskanen L, Gylling H, Atalay M, Rauramaa R, Uusitupa M. Effect of weight loss on cytokine messenger RNA expression in peripheral blood mononuclear cells of obese subjects with the metabolic syndrome. Metabolism 2008; 57: 192-199

42 Skurk T, Mack I, Kempf K, Kolb H, Hauner H, Herder C. Expression and secretion of RANTES (CCL5) in human adipocytes in response to immunological stimuli and hypoxia. Horm Metab Res 2009; 41: 183-189

43 Fruhbeck G. Overview of adipose tissue and its role in obesity and metabolic disorders. Methods Mol Biol 2008; 456: 1-22

44 Wozniak SE, Gee LL, Wachtel MS, Frezza EE. Adipose tissue: the new endocrine organ? A review article. Dig Dis Sci 2009; 54: 1847-1856

45 Smid SD, Bjorklund CK, Svensson KM, Heigis S, Revesz A. The endocannabinoids anandamide and 2-arachidonoylglycerol inhibit cholinergic contractility in the human colon. Eur J Pharmacol 2007; 575: 168-176

46 Fioravanti B, De Felice M, Stucky CL, Medler KA, Luo MC, Gardell LR, Ibrahim M, Malan TP Jr, Yamamura HI, Ossipov MH, King T, Lai J, Porreca $F$, Vanderah TW. Constitutive activity at the cannabinoid CB1 receptor is required for behavioral response to noxious chemical stimulation of TRPV1: antinociceptive actions of CB1 inverse agonists. J Neurosci 2008; 28: 11593-11602

47 Motter AL, Ahern GP. TRPV1-null mice are protected from diet-induced obesity. FEBS Lett 2008; 582: 2257-2262

48 Zhang LL, Yan Liu D, Ma LQ, Luo ZD, Cao TB, Zhong J, Yan ZC, Wang LJ, Zhao ZG, Zhu SJ, Schrader M, Thilo F, Zhu ZM, Tepel M. Activation of transient receptor potential vanilloid type-1 channel prevents adipogenesis and obesity. Circ Res 2007; 100: 1063-1070

49 Landsman RS, Makriyannis A, Deng H, Consroe P, Roeske WR, Yamamura HI. AM630 is an inverse agonist at the human cannabinoid CB1 receptor. Life Sci 1998; 62: PL109-PL113

50 Ross RA, Brockie HC, Stevenson LA, Murphy VL, Templeton F, Makriyannis $A$, Pertwee RG. Agonist-inverse agonist characterization at $\mathrm{CB} 1$ and CB2 cannabinoid receptors of L759633, L759656, and AM630. Br J Pharmacol 1999; 126: 665-672

51 Hoareau L, Buyse M, Festy F, Ravanan P, Gonthier MP, Matias I, Petrosino $S$, Tallet F, d'Hellencourt CL, Cesari M, Di Marzo V, Roche R. Anti-inflammatory effect of palmitoylethanolamide on human adipocytes. Obesity (Silver Spring) 2009; 17: 431-438

52 Villanueva A, Yilmaz SM, Millington WR, Cutrera RA, Stouffer DG, Parsons $L H$, Cheer JF, Feleder $C$. Central cannabinoid 1 receptor antagonist administration prevents endotoxic hypotension affecting norepinephrine release in the preoptic anterior hypothalamic area. Shock 2009; 32: 614-620

53 Nilsson O, Fowler CJ, Jacobsson SO. The cannabinoid agonist WIN 55,212-2 inhibits TNF-alpha-induced neutrophil transmigration across ECV304 cells. Eur J Pharmacol 2006; 547: 165-173

54 Marchalant Y, Rosi S, Wenk GL. Anti-inflammatory property of the cannabinoid agonist WIN-55212-2 in a rodent model of chronic brain inflammation. Neuroscience 2007; 144: 1516-1522

55 Kimball ES, Schneider CR, Wallace NH, Hornby PJ. Agonists of cannabinoid receptor 1 and 2 inhibit experimental colitis induced by oil of mustard and by dextran sulfate sodium. Am J Physiol Gastrointest Liver Physiol 2006; 291: G364-G371 
56 Cencioni MT, Chiurchiu V, Catanzaro G, Borsellino G, Bernardi G, Battistini L, Maccarrone M. Anandamide suppresses proliferation and cytokine release from primary human T-lymphocytes mainly via CB2 receptors. PLoS One 2010; 5: e8688

57 Vercelli CA, Aisemberg J, Billi S, Cervini M, Ribeiro ML, Farina M, Franchi $A M$. Anandamide regulates lipopolysaccharide-induced nitric oxide synthesis and tissue damage in the murine uterus. Reprod Biomed Online 2009; 18: 824-831

58 Chung S, Lapoint K, Martinez K, Kennedy A, Boysen Sandberg M, McIntosh MK. Preadipocytes mediate lipopolysaccharide-induced inflammation and insulin resistance in primary cultures of newly differentiated human adipocytes. Endocrinology 2006; 147: 5340-5351



59 Isakson P, Hammarstedt A, Gustafson B, Smith U. Impaired preadipocyte differentiation in human abdominal obesity: role of Wnt, tumor necrosis factor-alpha, and inflammation. Diabetes 2009; 58: $1550-1557$

60 Wang B, Wood IS, Trayhurn P. Hypoxia induces leptin gene expression and secretion in human preadipocytes: differential effects of hypoxia on adipokine expression by preadipocytes. J Endocrinol 2008; 198: 127-134

61 Wang B, Wood IS, Trayhurn P. PCR arrays identify metallothionein-3 as a highly hypoxia-inducible gene in human adipocytes. Biochem Biophys Res Commun 2008; 368: 88-93 